\title{
POVERTY'S CHALLENGE TO THE STATES
}

\author{
TERRY SANFORD*
}

Anticipate charity by preventing poverty; assist the reduced fellow-man . . . by teaching him a trade or putting him in the way of business, so that he may earn an honest livelihood, and not be forced to the dreadful alternative of holding out his hand to charity.

\section{-Maimonides}

\section{I}

Poverty and the American System of Government

The American Society has begun a significant shift in its philosophy toward "the reduced fellow-man." In the affluent sixties, the faces of poverty haunt our consciences as we discover its many moods and sources. Poverty can be the family suddenly fatherless, the handicapped individual with insufficient means to relieve his suffering, the child born into life without family, the blue-collar worker pushed out by the machine, the Negro struggling in a white man's world, the marginal farmer in an increasingly urban America, the coal miner in the age of nuclear energy, and the ill-educated in a time which increasingly demands education.

Early America left the treatment of the poor to private charity and scattered government aid and activity. The aid was usually dispensed with a charity philosophy and the most common method of treatment was the poorhouse or other specialized institutions which segregated the extreme cases from society's view. Some communities drove the poor from the city's gates. As time passed, political organizations in the large cities developed welfare programs suited to their own purposes more than to the poor. Later some cities and states developed specialized programs to aid the most appealing groups of the poverty-stricken-the abandoned mothers, the elderly, and the blind.

The depression of the I930s focused the nation's attention on the poverty question as America realized that private and local and state governmental efforts were inadequate. The New Deal stimulated new federal programs which embodied a "work-for-relief" principle and direct support for certain categories of our poorsuch as those over sixty-five, the needy blind, and dependent children. The challenge to the whole American system caused a re-evaluation of the role of government and the development of the concept of government as the guardian of the economy. The federal government instituted safeguards for the investor, the banks, the housing industry; it provided loans, regulated the monopolies, assured the compensation of the unemployed, and stimulated the economy by conscious government policy.

- A.B. 1939, LI.B. 1946, University of North Carolina. Governor of North Carolina, 196r-65; currently heading "A Study of American States" at Duke University under grants from the Ford Foundation and the Carnegie Corporation. Author, But What About the People? (Ig66). 
Recovery was the byword, but there was a strong feeling that the government should never let a depression happen again.

Several states began serious efforts at developing their industrial base through campaigns to attract new industry into the states. But within the states the areas of economic need could not compete for industry with the areas where life was better, and the neglect continued.

\section{A. Where We Are}

How far has America come? It is difficult to measure the success of America's efforts against poverty in individual terms, but some facts can be stated. In 1962 , the Conference on Economic Progress issued a detailed analysis on the condition of poverty as of 1960 in the United States. Using the annual income guidelines to measure poverty-that is, under $\$ 4,000$ for families and under $\$ 2,000$ for unattached individuals - the Conference found that over one-fifth of the nation's population was living in poverty. While this number had been decreasing at a rate of 2.2 per cent per year between 1929 and $x 960$, there still were in 1960 nearly 37 million impoverished Americans-one-third of them children.

But these gross figures paint only a partial picture. In the last few years it has become increasingly apparent that entire segments of our society have been unable to elevate themselves above a poverty situation. There are those living in the Appalachias and the Ozarks, in the stifling ghettoes of New York, Chicago, and Los Angeles, and those who must hang tenaciously to the crop-weary lands which can no longer produce a living wage. All of these and more have been bypassed and left behind by our society. These are not cases. They are people-our people.

And what is the cost to us? We can measure the cost of lost productivity, of lost purchasing power, and of the relief rolls. But how do we measure the cost of a crushed spirit or a dead dream or a long-forgotten hope? What is the incalculable cost to us as a people when the children of poverty become the parents of poverty and begin the cycle anew?

The evidence seems to indicate that our governmental system has coped with only part of the poverty problem. In the past few decades, it has provided programs which maintained many people at or below a minimum subsistence level-while not reaching others at all.

With all of the effort in the New Deal and since, with all of the postwar economic boom in this country, still one-fifth of the American people do not earn enough to feed, clothe, and house themselves. Why? Why haven't we done the job by now? Where have we failed?

\section{B. The Myths That Block Us}

There are many answers, but at least part of the answer lies in a number of myths that all of us have shared about our economy, our society, and ourselves. 
The first is the explicit faith that so many of us have held that our economic system will overcome, in the long run, most of the obstacles facing our society. By developing our economy fully, and using the resources of the government wisely, we believed that unemployment would fall, incomes would rise, and poverty thereby would automatically be reduced. While there is evidence that economic development has much to do with helping some of the poor, there is also ample evidence that an increase in economic growth does not touch most of the poor. Increased opportunities do not help those who are unable to take advantage of them. There are some obstacles which our economic system alone will not overcome.

The second myth is the myth of Horatio Alger-that if a person has the energy and the will to work, he will be able to make his way. In a sense, this means that poverty and unemployment are a result of choice, not a condition of society-a manifestation of laziness, not economic isolation. The depression jolted this belief when millions of Americans, who were left jobless through no fault of their own, were also powerless to help themselves at all. The economy had let them down and so had the American way of life. Government assumed the role of the protector-of the old, the very young, the unemployed. But even with Social Security, Aid-to-Dependent Children, Unemployment Compensation, and others, the feeling has remained that a bit of Horatio Alger exists in us all, if each of us only will work hard to succeed.

A third myth which has held back action against poverty is the status quo myththat things are basically fine, we have the tools to conquer the problems we face, and really only need to change or adjust some minor mechanism of government to reach those few people who need help. Therefore, governmental agencies and their programs, operating for years, do not need changing or redirection but just need more money and more people to work for them. Consequently, when government acts, it usually turns to more of the same, solidifying the old structure and programs rather than seeking possible new solutions to the problems of a changing society. And this old structure has given birth to new problems: a housing program which eats up suburban land while the inner city slowly crumbles and decays; a welfare program which does not give enough to get by nor provide a path out; an agricultural program which thrusts vast changes on our farm population while failing to prepare the farmer for his withdrawal to the cities; and an educational system keyed to college and middle-class goals, leaving many behind who do not share those goals. And this does not exhaust the examples.

Government must be flexible, alert to change, coordinated and personal. The old textbook three-layered system of government with state, local, and federal governments clearly assigned their tasks has already given way to a compartmentalized approach based on government responsibilities. Communication up and down the line is much better than communication between activities-a county welfare agent talks easily and often to his superiors at the state and federal level but rarely to the county health agent. Today problems span the responsibilities of government and 
yet administrators and the departments see these problems in their own terms. The poverty problem is seen as a problem of welfare by welfare departments, as a problem of education by education departments, as a problem of health by health departments, and so on. While elected officials like the governor are held responsible for carrying out these programs, in fact they have little or no control over these segmented activities.

What is needed is a multi-pronged, coordinated attack rather than an attack by parts of government on parts of problems. Michael Harrington, America's foremost analyst of the poverty program, has said: ${ }^{1}$

In case after case, it has been documented that one cannot deal with the various components of poverty in isolation, changing this or that condition but leaving the basic structure intact. Consequently, a campaign against the misery of the poor should be comprehensive. It should think, not in terms of this or that aspect of poverty, but along the lines of establishing new communities, or substituting a human environment for the inhuman that now exists.

The fourth myth which has blocked effective action against poverty revolves around the ready tendency of Americans to believe that money will solve all our problems. Too often the initial governmental action has been a reflex to a symptom rather than a thoughtful response to the actual problem. Too little pre-planning goes into our governmental actions, and too often we find ourselves investigating a crisis rather than anticipating it. Examples abound in our history, but none seems as potent as the fact that there are still over one-fifth of our citizens living in poverty, despite all the programs and economic development we have achieved in the last three decades.

But a government alert to change is not enough. It must be responsive to the voices of those who need its help. When it is not representative, it cannot listenand when it cannot listen, it ceases to be responsive. Increasing malapportionment of legislative bodies and the disfranchisement of segments of our population has undoubtedly had the effect of reducing or restricting the voice of the poor. Thus, we are just beginning to heed the cry for a fair share of tomorrow's blessings.

For all of these reasons and more, our governmental system has been doing only a partial job on the problem of the impoverished American. No level of government is exempt from this indictment. The federal government, active in the general field of welfare for several decades, chose the year 1964 to declare war on poverty. The states, active in this area for a longer period, have a spotty record of achievementfor only a few have exerted any great effort or shown much initiative in this problem, except recently in response to the new federal program. Generally, the problem has fallen to the local community, with its limited resources and abilities. Local response has been equally uneven: extending from the Community Chest approach to the "Ioo Neediest Cases Fund" each Christmas; from the private efforts of the neighbor-

${ }^{1}$ Mrchael Harrington, The Other America: Poverty in the United States i68 (1963). 
hood church to the overtaxed, understaffed and underfinanced local welfare agency.

But no level of government has done enough, for massive problems demand massive support.

II

Formula for the Future: Community Action and InNovation

The new approach to the battle against poverty had to be unique. It needed to be able to overcome the shortcomings of prior efforts while at the same time using the very positive parts of existing programs. It needed to involve all parts of the community and not segments. The whole problem needed to be tackled and not just parts of it. The new technique would be community action, the keystone of a broad-based antipoverty effort, and innovation preserving the best of the old with the promise of the new.

By innovation in approach I do not mean a whole new series of programs suddenly pressed into service. This is not what innovation means. Innovation in the antipoverty program takes the best of the broad variety of programs now available, combines it with new ideas to provide the total effort with flexibility to fit all the problems. The approach might be likened to a supermarket, with a varied display of programs from which to choose, along with the ingredients to mold a whole new program. The particular mix desired and developed depends on the definition of poverty brought to the market by the community. This allows for initiative, innovation, and diversity in the development of programs rather than preconceived and prestructured answers to a dynamic and changeable problem.

In addition, the new definition of community action stresses an inclusive definition of community-including representation from the poor themselves. This means that a new umbrella organization would be created to cut across all the vertical strands of government, such as welfare, health, education, and so forth, and to join with those in the non-governmental sphere, such as churches, private philanthropic agencies, and a cross section of the citizenry. This community action organization was to look into the community mirror and devise its own answer. Not only did this broad-based organization force some of the rigid professional boundaries to be breached and questioned, but it also allowed the entrance into the market of many of those previously excluded. In this way, new voices would become part of the process. That this was a revolution is obvious-but a revolution within a structure established to encourage revolution.

We in North Carolina recognized these two components when we established The North Carolina Fund in the summer of 1963 , with grants of $\$ 7$ million from the Ford Foundation, matched by grants from Reynolds and Babcock foundations, and state and local funds. In announcing the establishment of the Fund, I said,

There are tens of thousands whose dreams will die. Some of this poverty is selfimposed and some of it is undeserved. All of it withers the spirit of children, who 
neither imposed it nor deserve it. These are the children of poverty who tomorrow will become the parents of poverty. We hope to break this cycle of poverty. That is what The North Carolina Fund is all about.

We wanted to have the freedom to go into the communities of the state and say to the leaders of schools, government, welfare, health, charity: "Look, let's work together; let's see if together in a few neighborhoods near here we can't break the cycle of poverty and give these children a better chance."

We wanted the community, the entire community, first to analyze its own situation and then to come up with what it felt would alleviate the problems. We were gratified that sixty-six of our roo counties were represented in such self-analyses and submitted proposals. Some proposals called for more of the same; others wanted striking new approaches. Some proposals could best be implemented by tinkering with the existing governmental machinery; others needed new machinery established. When there was a pattern, maybe a statewide program was needed. When it was unique, The North Carolina Fund would support the community in its innovation. Unfortunately, our funds did not allow us to satisfy the tremendous response we received, and we had to select certain proposals as pilot projects-both statewide and community based. But all the communities were interested in a broader effort than was being made at the time.

We already see results. The first impact was to upset the existing power structures within communities so that changes in the status quo could occur. In most cases this amounted to radical changes in community relations and activities-but this we did knowingly, realizing that positive results would occur when existing structures are challenged by the new.

This process of self analysis seemed to awaken the community conscience. The important thing in my mind was that we established a vehicle by which a community approach in its broadest sense was undertaken, encouraged a new look, and made provision for creative innovation in developing solutions.

The Economic Opportunity Act of 1964,2 which embodies the nationwide commitment against poverty, was based on these same two components: community action and innovation. The success or failure of the antipoverty program is in the future, but the history of the national effort to date indicates that the existing order is being challenged on all fronts and that communities are beginning to probe their consciences. Critics charge mismanagement, unclear plans and goals, programs in shambles, "politicos" using the poverty war for narrow purposes, poor communication, agencies and whole levels of governments being bypassed. Some complaints are contradictory: too little coordination, too much coordination, no guidelines, too many guidelines-all these and others represent the beginnings of the significant shift we have taken in our philosophy toward the reduced fellowman in our midst.

But, regardless of objections, our governmental system is carrying this fight to

${ }_{78}^{2}$ Stat. 508, 42 U.S.C. $\$ 270$ ( 1964 ). 
every community and every part of society in the nation, with the overwhelming commitment of the federal government serving as the stimulant. Local communities everywhere are evaluating their situations and submitting proposals to the Office of Economic Opportunity in Washington for approval and funding. The states are being asked to aid the local communities in this effort and to mobilize the states' resources to achieve the goals of the programs. And the federal government is providing the guidance and the funds for the massive effort.

\section{III}

\section{The Role of the States}

The antipoverty program is less than two years old, and much is still in the definition stage. However, there appears to be a trend in development which, in the long run, may serve to reduce the potential results of the program. The trend I speak of is the unclear definition of the role of the states in the program and the fuzzy set of relationships between all the levels of the governmental system.

In many respects, the states are the key to the operation of the federal system of government. I am not arguing from the constitutional position that all other governments in our system derive their grant of authority from the states. Nor am I arguing from the political position that shows that our state political systems are the basis of the national political system. The position $I$ am arguing from is based on an understanding of how our governmental system operates-that the states are a major partner in almost all the federal domestic programs, and are a vital resource which ought to be summoned to the front lines of the battle. Highway programs, health programs, the new recreation program, the new education programs, the welfare programs and others are all combinations of federal-state funds and standards. And many states were active in these areas before federal funds and standards were added.

Critics argue that the states have so often neglected their responsibilities in these areas that national programs were necessary. While this certainly is true of the need for national action in aiding urban areas, the voting rights bill, and the reapportionment question, there are many cases of states performing the role of the experimenter and the innovator, in which they have demonstrated the need for wider programs through their successes. The first antitrust statutes were developed by the states; the first maximum hours-minimum wage legislation was developed by the states; the states fashioned the first anti-discrimination statutes, the first child labor laws, the first unemployment insurance.

The point is that all levels of government are new to the problems of poverty, and that no level has a monopoly on solutions. The states, like all levels of our system, are already involved in the problems of poverty through their welfare, education, health, employment and other activities. They are providing many of these services now, and the concept of innovation which I have discussed previously does 
not only look to the new, but a mixture of the new with the old, to achieve the goals of the program.

For that reason the states have a crucial role in the development and administration of the antipoverty program, and this role may be the key to its success. To date, there has been little or no support for the states to take much of a positive role; and their role has been left vaguely defined. With such a national commitment to a program, it is time for the states to move fully into the fray. It may be true that the states neglected the area of poverty in the past, but they were not alone in this. And, as I have stressed throughout this discussion, success will be achieved by bringing to bear all the resources available on the problem. The states can be a major resource.

There are at least four types of activities for which the states are uniquely suited. Some are already being performed by a few of the states.

I. Technical Assistance, Communication and Interpretation. The states should be the fulcrum of the federal system. Halfway between the national and local government, the states are situated so that they can be either bottlenecks or positive participants in the overall process. Section 209 (b) of the Economic Opportunity Act of $\mathrm{rg64}$ recognizes the unique contribution that states can make and provides for grants to state technical agencies for coordination and communication. ${ }^{3}$ The state agency in this case serves on call for the interested communities and agencies to aid them to understand the various provisions of the program and to apply for grants. For small communities, often mystified and discouraged by federal procedures, this state agency can make the difference as to whether many communities will participate in a poverty program at all.

Most states are doing this at the present time in their antipoverty programs, but it is not enough. With the high funding ratio (90-Io federal-state) in which the states' ten per cent can be in kind rather than cash, these agencies virtually become extensions of the federal Office of Economic Opportunity rather than state agencies adding the resources of the state to the battle. While this role is crucial in getting the nationwide poverty program underway and making its impact complete, it must not be the states' only effort. For once the program is interpreted, and the various communities and agencies are operating programs with grants from the federal Office of Economic Opportunity, the need for such an office at the state level may disappear. Thus, interpretation and communication is only the first step rather than the total role to be played.

2. Stimulation of Antipoverty Efforts. Using the same agency and funding available under section 209 (b), the state agency can move out into the state at large and into the various governmental agencies and stimulate the necessary programs to be undertaken. It need not wait to be called upon. The agency can stimulate and challenge the communities and agencies to fulfill their responsibility. The state

${ }^{3} 78$ Stat. 519, 42 U.S.C. $\$ 2789$ (b) (1964). 
agency can take the initiative in getting statewide efforts underway where a statewide effort is preferable to a piecemeal community-by-community approach. Often the state agency will initially undertake the program itself and spin it off once underway when a suitable home can be found.

Several states have perceived their role in this manner. New Jersey, with the strong backing of Governor Richard Hughes, has been using an affirmative state office approach and thereby has been able to obtain a "greater variety of grants covering more of its people than any other state in the union," according to OEO Director R. Sargent Shriver. Some of the programs are developed and run directly by the state office. California, with an equally aggressive approach under Governor Edmund G. Brown, has been a leader in developing rural area programs and a very impressive migrant labor program-created and initiated in the State Coordinator's Office. There are other examples, but I fear too few. This type of an approach means an active commitment and involvement by the governor and the state in the program. There is nothing preventing the states from filling such a role except their own lack of imagination and leadership.

Many states have been distracted from this positive approach by the question of the governor's veto over community action program proposals within the state. The argument on the one side is that the veto involves the governor and thereby the state in the programs and allows for a certain degree of control. The other side of the argument is that the veto acts as a negative control rather than affirmative leadership. It is ex post facto, coming after the planning, development, funding and announcement stages-thereby presenting the governor with an unhappy choice of just going along or stopping a program which has the support and commitment of many people. Further, its use has stimulated reaction from Congress to restrict the governor in the future. The answer is that the veto can be used constructively if combined with a positive state approach. It can serve as another weapon in the governor's arsenal to prod and stimulate agencies and communities in the proper direction. It can serve as the entrée for the governor to become an active part of the planning and development process.

3. Coordination of Governmental Activities. Coordination of governmental activities is a concept which excites the reformer and frightens the participant. Although everyone pays it lip service, it is a concept which is ignored throughout our governmental system, and the poverty program is no exception. According to the United States Conference of Mayors,

Most of the Community Action Agency Directors reported that they had not encountered meaningful coordination between (the federal) Office of Economic Opportunity and the so-called delegated programs operating through the Department of Labor, the Department of Health, Education and Welfare and various other departments. ... If local communities are expected to achieve any effective program development of a comprehensive and coordinated sort, the OEO must take the initiative among the federal agencies which the local Community Action 
Agencies are powerless to affect. This administrative failure, if allowed to conttinue, constitutes the most serious threat to the effective operation of a local umbrella agency currently on the horizon. ${ }^{4}$

This points out several important facts to be considered: first, coordination of effort by all levels of government is necessary for the success of the program; second, coordination at the federal level has not really occurred and without coordination at this higher level, lower levels cannot meaningfully initiate or influence programs; and, third, the local communities face an impossible task in attempting to coordinate all the governmental activities which focus on them. The local communities do not possess personnel or resources; they suffer from a more parochial view of the world which leads to an inability to relate local particular problems to broader trends; and they do not have political muscle to force other levels to coordinate efforts.

The states can do part of this coordination job with the programs and agencies concerned with the poverty effort. The states already are a key to the operation of the federal system of government, as a major partner in almost all the federal domestic programs. They are responsible for administering most of the existing services and have impressive resources to bring to bear on the various problems. As entities more regional than local communities, they have a broader view and are more able to relate particular problems to broader trends. They may not be the perfect regional entities to carry this out, but they exist with a considerable present administrative structure, a power base and loyalty.

The logical place to vest responsibility for coordination is in the office of the governor. The governor is the only man representing his state who is acutely aware of the problems it faces in education, health, welfare, finances, mental health, urban renewal and poverty. In almost every state, the responsibility for initiation of major statewide programs falls upon the governor. He must, like the President of the United States, energize his administration, search out the experts, formulate the programs, mobilize the support, and carry through with the idea. Few major undertakings ever get off the ground without his support and leadership. The governor sets the agenda for public debate; frames the issues; decides on the timing; and can blanket the state with good ideas by using his access to the mass media. His office is really the only place where statewide coordination can occur.

4. Planning and the Setting of Priorities. The major criticism of the antipoverty program to date is the lack of adequate planning and setting of priorities in the development of the various programs. The supermarket approach makes programs available to attack all types of problems-but it is up to the local communities to pick and choose as they desire. At times, what one community does in answer to its problems may add to the problems of the next community, the region, or the state. For example, in some rural areas, separate communities, each offering retraining programs for high school dropouts, could glut the market with similarly trained

- U.S. Conference of Mayors, Special Report: The Office of Economic Opportunity and local Community Action Agenctes 4 (1965). (Emphasis added.) 
people-to the disadvantage of both the community and the people. Likewise, there is need to ensure the best priority of effort, so that programs build on each other rather than compete for the limited resources and energy at hand.

The local community sets its own priorities and the federal OEO reviews them, but who relates the priorities established by a series of communities within the same region, or just beyond that region? The problems of our society flow in major part from its complexity. Yet, the emphasis on local communities acting individually or at best with several other communities in defining their problem and in devising their answer may potentially be overlooking the very complexity it seeks to meet. I agree with the efforts to seek multi-county approaches such as Georgia and Indiana have used, and also with the increasing emphasis that the federal OEO places on this approach.

But poverty is too complex to yield to a one-dimensional approach. Our society is not made of neatly contained, self-functioning units. Problems often are not encompassed by political boundaries.

Look at the Appalachian Regional Development Program. Twelve states, the federal government, and the local communities are attempting to focus the resources of all on a common condition-poverty in rural Appalachia. The impetus came from the governors themselves, who had long known that poverty lurked in the valleys and the hills of this mountain chain that stretched over twelve states. But we had never defined the problem in quite that way. This new way of thinking about an old problem gave life to a whole new set of proposals and programs. The framework guided the effort. We soon came to realize that decisions made within one region have an impact well beyond its bounds, and events outside bring severe repercussions within the region.

With this sort of framework for action, the states could be turning to their own "Little Appalachias." They could be designing fresh approaches to meet the challenges of an era when populations and problems ignore the old city limits and county lines. As a funnel for funds, the states could act to bring together the strands of government. They should present the communities with an array of possible programs and aid them in fitting new approaches into the overall effort.

We need proper planning and the setting of priorities within an overall framework. Problems need definition and pinpointing. Trends must be discerned and areas defined. Programs like Appalachia must be meshed with the poverty program. Goals and the means to these goals must be set. Priorities and timing of activities should be suggested.

The states are in the best position to carry out this charge. The federal government looks at problems and programs in broad, general, aggregate terms. Local communities see the world in narrow, particular, individual terms. The states, as regional, territorial entities, are best equipped to bring these two viewpoints into focus to the benefit of those receiving the service. Further, they sit at a key point 
in the provision of services to the people and probably have the best chance to effectuate plans.

The future, however, will depend on the states' own action-their willingness to take on the responsibility and challenge this represents. Some states are taking the first steps in this direction. Illinois and Massachusetts have used portions of their state technical assistance funds to gather and analyze data relating to the poverty situation within their bounds. The North Carolina Fund, from its inception, has maintained a strong emphasis on the research and planning function, with its first publication setting out the profile of poverty in the state. The next step in all these efforts is to relate the data to policy and program decisions and to translate their meaning to the communities in the state. This is the major role which the states can play, not just in this program, but in all programs-and it really means making government more responsive and effective.

IV

\section{Poverty in Perspective}

Whether we acknowledge it or not, the realities of American growth and the demands of the American people are recasting American government along new and more exacting lines. For America is, as James Madison prophesied, a system of interacting federalism-and the influence of the states will fluctuate with their responsiveness to the needs of the times and the demands of the people.

Most people do not realize that the states are spending more than $\$ 40$ billion a year on services to the American people. In the two decades since the Second World War, their budgets have risen at a faster rate than the federal budget. They pass most of our laws; run our courts and our prisons; do most of what's done for the mentally ill; and have the largest responsibilities for education.

Despite the persistent arguments over the last twenty years that states have ceased to be progressive and should therefore be abandoned as obsolete, the facts remain: states are here, they are here to stay, and in terms of services and functions, they are stronger than they have ever been before.

But the future of the states will depend on the energy with which they attack the problems of the nation. As I said recently in a speech to the Midwestern Governors' Conference,

It is when the states fail to meet their responsibilities in such areas as education, civil rights and liberties, enhancing the opportunities of the poor, and urban affairs that the federal government moves into the vacuum. It is when the states are not responsive, are not laboratories of experimentation, do not reach all the people because they are either oppressive or not representative, that the states forfeit their strongest argument for a future.

This is poverty's challenge to the states-to respond to the summons of the people. But it will take more than talk and more than interest and even more than a willing- 
ness to act. The states must be able to act. They must initiate a period of total reform which will do away with the weak governor, unrepresentative legislatures, chaotic administrations, and archaic judiciaries. To conquer the future, the states must first conquer themselves.

Most Americans tend to believe that there is something inherently good about the federal system. Our high school civics books teach us it is the best. However, no form of government is inherently good. It can be judged only in terms of the quality of the civilization it helps to produce and to sustain.

If the states can help to abolish poverty in America, they will have contributed to a more civilized nation. And by fueling the light of hope for millions of Americans, they can give fiber to the American dream and set a new course for themselves as active partners in a revitalized federal system. 